\title{
Evaluation of Physicochemical Characteristics of Surface Water from Orashi River, Rivers State, Southern Nigeria
}

\author{
By Onisogen Simeon Edori ${ }^{*} \&$ Enize Simeon Edori ${ }^{ \pm}$
}

\begin{abstract}
Water samples were collected from four different stations bimonthly from the Orashi River for a period of one year. The samples were collected from the shores of selected communities along the Engenni axis of the river. The samples were treated and analyzed according to standard laboratory and analytical procedures for water physicochemical parameters. The parameters examined were $\mathrm{pH}$, Salinity, chlorides $(\mathrm{Cl})$, Conductivity, total dissolved solids (TDS), total suspended solids (TSS) turbidity, temperature, dissolved oxygen (DO), biochemical oxygen demand (BOD), chemical oxygen demand (COD), nitrates $\left(\mathrm{NO}_{3}{ }^{-}\right)$, sulphate $\left(\mathrm{SO}_{4}{ }^{2-}\right)$ and phosphates $\left(\mathrm{PO}_{4}^{3-}\right)$. The results showed that the mean values of the evaluated parameters were; $p H(6.91 \pm 0.11)$, salinity $(9.79 \pm 0.27 \mathrm{mg} / \mathrm{L}), \mathrm{Cl}^{-}(6.25 \pm 0.25 \mathrm{mg} / \mathrm{L})$, conductivity $(29.66 \pm 1.20 \mu \mathrm{S} / \mathrm{cm}), \mathrm{TDS}$ $(17.66 \pm 2.08 \mathrm{mg} / \mathrm{L}), \quad T S S(16.83 \pm 1.15 \mathrm{mg} / \mathrm{L})$, turbidity $(11.84 \pm 1.50 \mathrm{mg} / \mathrm{L})$, temperature $\left(28.16 \pm 0.12{ }^{\circ} \mathrm{C}\right), \mathrm{DO}(5.91 \pm 0.18 \mathrm{mg} / \mathrm{L}), B O D(7.30 \pm 0.60 \mathrm{mg} / \mathrm{L})$, $\mathrm{COD}(9.41 \pm 0.70 \mathrm{mg} / \mathrm{L}), \mathrm{NO}_{3}^{-}(3.42 \pm 0.27 \mathrm{mg} / \mathrm{L}), \mathrm{SO}_{4}{ }^{2-}(1.15 \pm 0.56 \mathrm{mg} / \mathrm{L})$ and $\mathrm{PO}_{4}^{3-}(15.65 \pm 5.76 \mathrm{mg} / \mathrm{L})$. The results of the different parameters showed that all of them fall within the WHO acceptable limit except turbidity, DO and BOD that were not within the recommended range, then COD and phosphates that were either within or above the recommended values at different instances. Based on the findings of this work, the water may not be particularly suitable for drinking purposes, but can be used for other household functions that do not require consumption and also for irrigation.
\end{abstract}

Keywords: water, physicochemical property, human activity, environment, contamination

\section{Introduction}

Water is an indispensable part of human existence. It is very crucial for agricultural processes, industrial processes, movement of transport of goods and services from one place to the other. Although water is notably important in the driving of human progressive processes, its management as a resource of utmost importance is very poor (Fakayode 2005). The concept and reality of the divers and numerous sources of water contamination, the attendant methods applied for its purification and the cost effects arising from these man made effects are worthwhile issues of concern all over the world. The level of water deterioration occasioned by human activities and natural causes is ever increasing. Even the natural factors which are supposed to occur on their own are now accelerated due to human incursions into the environment. These combined effects (human and natural) are now a threat to both plants and animals (Iyama et al. 2020).

*Lecturer 1, Department of Chemistry, Ignatius Ajuru University of Education, Nigeria.

${ }^{ \pm}$Post Graduate Student, Department of Chemistry, Ignatius Ajuru University of Education, Nigeria. 
The health of any water system is a function of physicochemical properties of the water, which impacts on the general behaviour of the ecosystem (Dudgeon 2011). Interferences by humans can change the chemistry of the aquatic system which can cause a behavioural change in terms of migration, relocation of habitat, cannibalism and general feeding behaviour (Bere and Tundisi 2011). The cycles of water regeneration and natural purification processes is also dependent on the physicochemical roles of the different species present in the water, which if allowed can manipulated the characteristics of the species present (without human interferences) to preserve the natural state of the water. These parameters are responsible for both direct and indirect signs of the situation of the aquatic environment and its capability of supporting communities of biological organisms (Lawson 2011).

Rivers flow through naturally defined channels and with constant contact with its banks which is gradually washed off into the river water (Lawson 2011). Every river is fed by runoffs, from glaciers and ice melting at high temperatures, from adjoining streams, overflowing water logged swamps, lakes, springs, rain water, snow etc. (Nnamani et al. 2015). Due to the importance of water as a natural resource, human settlements have been by the banks of rivers right from ages past all over the world. The essence of settling by the riverside is for the numerous uses such as transportation, irrigation, fishing, power generation, waste disposal and farming (Lawson 2011, Edori, 2020). Moreover, every year rivers (especially fresh water) overflows their banks, thereby making the lands by the banks very fertile for cultivation. The nature of water contamination varies between rural and urban settlements. While water contamination in rural settlement is due to normal agricultural activities and runoffs, urban water pollution is majorly from industrial wastes (Wokoma and Edori 2017). All of which results in poor water quality that requires proper treatment before use (Edori and Nna 2018).

Therefore, this study was undertaken to examine the variations of some physicochemical properties of surface water from parts of the Orashi River.

\section{Materials and Methods}

\section{Collection of Samples}

The water samples were collected from the surface of the water to a depth of $30 \mathrm{~cm}$ with plastic jerry cans. The jerry cans were previously washed and dry. The samples were collected from four different positions and their geographic positions recorded. The points where samples were collected and the geographic coordinates are given in Table 1. 
Table 1. The Geographic Positions and Communities where Samples were Collected

\begin{tabular}{|l|c|c|}
\hline Serial Number & Geographic Location & Community \\
\hline 1 & $4^{\circ} 107.3^{\prime} \mathrm{N}, 6^{\circ} 30^{\prime} 6.6^{\prime} \mathrm{E}$ & Odau \\
\hline 2 & $5^{\circ} 33^{\prime} 39.2^{\prime} \mathrm{N}, 6^{\circ} 26^{\prime} 58.7^{\prime} \mathrm{E}$ & Mbiama \\
\hline 3 & $5^{\circ} 9{ }^{\prime} 5.2^{\prime} \mathrm{N}, 6^{\circ} 25^{\prime} 47.6^{\prime \prime} \mathrm{E}$ & Okarki \\
\hline 4 & $4^{\circ} 59^{\prime} 10.1^{\prime} \mathrm{N}, 6^{\circ} 27^{\prime} 2.5^{\prime} \mathrm{E}$ & Okparaki \\
\hline
\end{tabular}

The samples were collected at intervals of two months for a period of one year, beginning from December 2018 - October 2019. The samples were immediately put into ice packs containers and transported to the Chemistry Laboratory of the Ignatius Ajuru University of Education, Rumuolumeni, Port Harcourt, Rivers State, Nigeria.

\section{Analysis of the Samples}

The examination of the $\mathrm{pH}$, conductivity and TDS were done insitu using a Jenway portable meter model 350 . Turbidity of the water samples were also done on site with a turbidity meter, HACH Model 2100An, while salinity was analyzed with a digital electronic meter at the point of sample collection. Total suspended solid (TSS) was evaluated using the filtration method (APHA 1995) and the results calculated as follows:

$\mathrm{TS} \mathrm{S}=\frac{\text { post weight of filter-pre weight of filter }}{\text { Volume of Sample used }(\mathrm{mL})} X 1000 \mathrm{~mL}$

The Winkler's method was used to determine the amount of dissolved Oxygen (DO) in the water and the values calculated as:

Dissolved Oxygen $=\frac{\text { Volume of sodium thiosulphate } \times 0.2 \times 1000}{\text { Volume of sample taken }}$

Biochemical oxygen demand (BOD) of the samples were analyzed on the previously DO examined samples after being kept for a period of five days in the dark at a temperature of $20{ }^{\circ} \mathrm{C}$. The result gotten was calculated and noted as $\mathrm{BOD}_{5}$.

Chemical oxygen demand (COD) was determined using the oxidation method (APHA 1995) and calculated as:

$$
\text { Chemical Oxygen Demand }=\frac{A-B \times N \times 8 \times 1000}{\text { Volume of sample taken }}
$$

Where

$\mathrm{A}=$ Volume of ferrous ammonium sulphate for blank

$\mathrm{B}=$ Volume of ferrous ammonium sulphate for the sample

$\mathrm{N}=$ Normality of ferrous ammonium sulphate

$\mathrm{V}=$ Volume of sample. 
For the determination of phosphates, mild acid hydrolysis method was used to convert phosphate present in the sample to orthophosphate and a colorimetric determination was done to find the concentration of phosphate in the sample. Phosphate concentration was calculated as:

Phosphate concentration $=\frac{\text { phosphate content } \times 1000}{\text { Volume of sample }}$

Sulphates and nitrates concentrations in the water samples were determined using the HACH spectrophotometer (model 3900 DR, USA). This was achieved by dissolving analytical water test tablets Sulpha Ver®4 and Nitra Ver®5 in $25 \mathrm{ml}$ into separate water samples. The final contents were determined at spectrophotpmetric wavelengths of $450 \mathrm{~nm}$ and $890 \mathrm{~nm}$ respectively and the results obtained by comparing with those of the respective blank in calibration curves from standard sulphate and nitrate solutions (APHA 1995).

Chloride concentrations in the samples were evaluated by titrimetric methods, which were compared with those of blank titrations. The concentration of chloride in the sample was calculated as:

Chloride concentration $=\frac{(V s-V b) \times \text { nomality } \times 35.5 \times 1000}{\text { Volume of sample taken }}$

Where

Vs $=$ Volume of silver nitrate used for the sample

$\mathrm{Vb}=$ Volume of silver nitrate used for the blank

\section{Results and Discussion}

\section{Chemical Parameters}

The results of the chemical parameters are shown in Table 2 and Figure 1. The chemical parameters examined in this research work are $\mathrm{pH}$, salinity and chlorides $\left(\mathrm{Cl}^{-}\right)$.

Table 2. Chemical Parameters of Water Samples from Orashi River at the Different Stations

\begin{tabular}{|c|c|c|c|c|c|}
\hline \multirow{2}{*}{$\begin{array}{l}\text { Chemical } \\
\text { Parameters }\end{array}$} & \multicolumn{4}{|c|}{ Stations } & \\
\hline & 1 & 2 & 3 & 4 & \\
\hline $\mathrm{pH}$ & $6.92 \pm 1.17$ & $6.90 \pm 1.08$ & $6.75 \pm 0.89$ & $7.07 \pm 1.07$ & $6.91 \pm 0.11$ \\
\hline $\begin{array}{l}\text { Salinity } \\
(\mathrm{mg} / \mathrm{L})\end{array}$ & $9.45 \pm 1.30$ & $10.10 \pm 1.32$ & $9.61 \pm 2.39$ & $10.01 \pm 2.35$ & $9.79 \pm 0.27$ \\
\hline $\mathrm{Cl}^{-}(\mathrm{mg} / \mathrm{L})$ & $6.45 \pm 1.06$ & $5.83 \pm 1.62$ & $6.27 \pm 2.14$ & $6.45 \pm 0.06$ & $6.25 \pm 0.25$ \\
\hline
\end{tabular}


Figure 1. Mean Monthly Variation of Chemical Parameters of Water Samples from Orashi River

December $\square$ February $\square$ April $\square$ June August $\square$ October

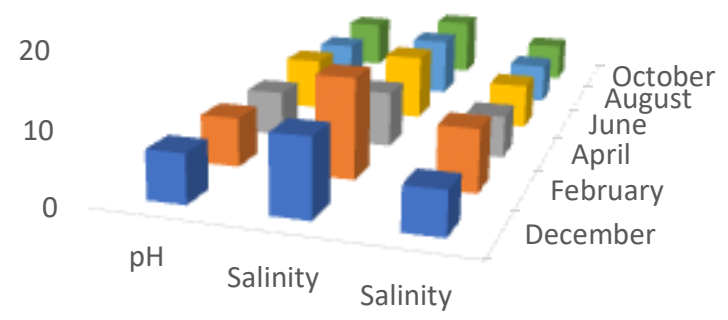

The $\mathrm{pH}$ varied from $6.75 \pm 0.89-7.07 \pm 1.07$ in the stations, while variation in the months ranged from $6.66 \pm 1.53-7.63 \pm 1.29$. The $\mathrm{pH}$ values observed in the river were within the WHO and NAFDAC value of $6.5-8.5$ for drinking water. The values of $\mathrm{pH}$ observed in this work are in agreement with the observation of other authors in similar environment (Nnamani et al. 2015, Adewuyi et al. 2017, Edori and Kpee 2018). The value range of $\mathrm{pH}$ observed in the river falls within the range of good water quality (Adewuyi et al. 2017). This value range is common in a flowing river due to the fact that whatever is discharged into is carried away immediately and so may not have time to impact on it. Secondly, the volume of water is large and since it is always in constant motion renews itself almost immediately and finally, the near absence of industrial activities along the river can be a factor that may also be responsible for non-interference of ionic species with the $\mathrm{pH}$, due to fewer concentrations present (Edori 2020).

$\mathrm{pH}$ specifies the strength of acido-basic behaviour of the water and is measured by the amount of dissolved substances and biochemical developments in the water medium (Saksena and Kaushik 1994). The $\mathrm{pH}$ of the water environment is often examined for valuations the health status of the ecological unit and its suitability for irrigation, drinking and other industrial and domestic uses (Mezgebe et al. 2015).

The salinity result obtained from the sampled stations varied from $9.45 \pm 1.30$ $-10.10 \pm 1.32 \mathrm{mg} / \mathrm{L}$, while those of the months varied from $7.85 \pm 1.63$ in April $13.95 \pm 3.29 \mathrm{mg} / \mathrm{L}$ in February. These values are lower than the WHO limit of $2000 \mathrm{mg} / \mathrm{L}$. The values of salinity observed in the Orashi River were within the range of values observed in Elelenwo River, Rivers State, Nigeria (Edori et al. 2020), but lower than the values observed in the Silver River, Bayelsa State, Nigeria (Edori et al. 2019).

Salinity controls the mass to volume ration of water and is the major cause of water stratification. The presence of raised values of water salinity can lead to corrosion of technological equipment and structures such as bridges. Salinity provides a situation for increased electric charge carriers which help in the exchange of electrons between charged species. Again, the health status of aquatic biomes is greatly affected by quantity of salinity and in extreme situations these 
are responsible for mortal consequences of aquatic flora and fauna (Edori et al. 2020).

Chloride values in the sampled stations varied from $6.45 \pm 1.06-5.83 \pm 1.62$ $\mathrm{mg} / \mathrm{L}$. The values observed in $5.67 \pm 1.04 \mathrm{mg} / \mathrm{L}$ in October to $8.67 \pm 2.63 \mathrm{mg} / \mathrm{L}$ in February. The concentrations of chlorides observed in the river were lower than the stipulated limit of $250 \mathrm{mg} / \mathrm{L}$ in drinking water by NAFDAC and WHO. The concentrations of chlorides in the Orashi River at the time of analysis were lower than the value observed in Cauveri River, India (Chandra et al. 2011) and those of Iyama and Edori (2014), in brackish water environment in the Niger Delta, Nigeria.

The presence of high concentration of chloride in water shows a sewage imposed water pollution. Human intake of water which contains elevated levels of chlorides is likely to be purged. Food crops planted in soil irrigated with water that contains high levels of chlorides will not likely produce reasonably (suffer reduction in yield). The low results of chlorides observed in the present work might be due to complete absence of industries along the area that may likely discharge used water into the river and non-contaminated runoffs. Chloride in water enhances electrical conductivity and corrosion rate of metallic materials (Edori and Nna 2018). Metals reacts with chlorides to form soluble salts, which results in increased concentration of heavy metals in water (WHO 2003), which implies that chlorides in water promotes metal corrosion Bay et al. 2003).

\section{Physical Parameters}

The values of the physical parameters are shown in Table 3 and Figure 2. These parameters include conductivity, total dissolved solids (TDS), total suspended solids (TSS), turbidity and temperature.

Table 3. Physical Parameters of Water Samples from Orashi River at the Different Stations

\begin{tabular}{|l|c|c|c|c|c|}
\hline \multirow{2}{*}{$\begin{array}{l}\text { Physical } \\
\text { Parameters }\end{array}$} & 1 & 2 & 3 & 4 & \\
\hline $\begin{array}{l}\text { Conductivity } \\
(\mu \mathrm{S} / \mathrm{cm})\end{array}$ & $29.29 \pm 4.64$ & $30.51 \pm 50.59$ & $30.97 \pm 6.66$ & $27.87 \pm 4.45$ & $29.66 \pm 1.20$ \\
\hline TDS $(\mathrm{mg} / \mathrm{L})$ & $17.42 \pm 3.39$ & $16.93 \pm 2.43$ & $21.00 \pm 4.61$ & $15.29 \pm 2.39$ & $17.66 \pm 2.08$ \\
\hline TSS $(\mathrm{mg} / \mathrm{L})$ & $16.07 \pm 2.36$ & $18.29 \pm 3.39$ & $15.40 \pm 2.38$ & $17.55 \pm 3.36$ & $16.83 \pm 1.15$ \\
\hline $\begin{array}{l}\text { Turbidity } \\
(\mathrm{NTU})\end{array}$ & $13.62 \pm 1.36$ & $13.03 \pm 3.39$ & $10.32 \pm 4.37$ & $10.40 \pm 3.63$ & $11.84 \pm 1.50$ \\
\hline $\begin{array}{l}\text { Temperature } \\
\left({ }^{\circ} \mathrm{C}\right)\end{array}$ & $28.04 \pm 0.20$ & $28.22 \pm 0.22$ & $28.32 \pm 0.21$ & $28.04 \pm 0.20$ & $28.16 \pm 0.12$ \\
\hline
\end{tabular}


Figure 2. Mean Monthly Variation of Physical Parameters of Water Samples from Orashi River

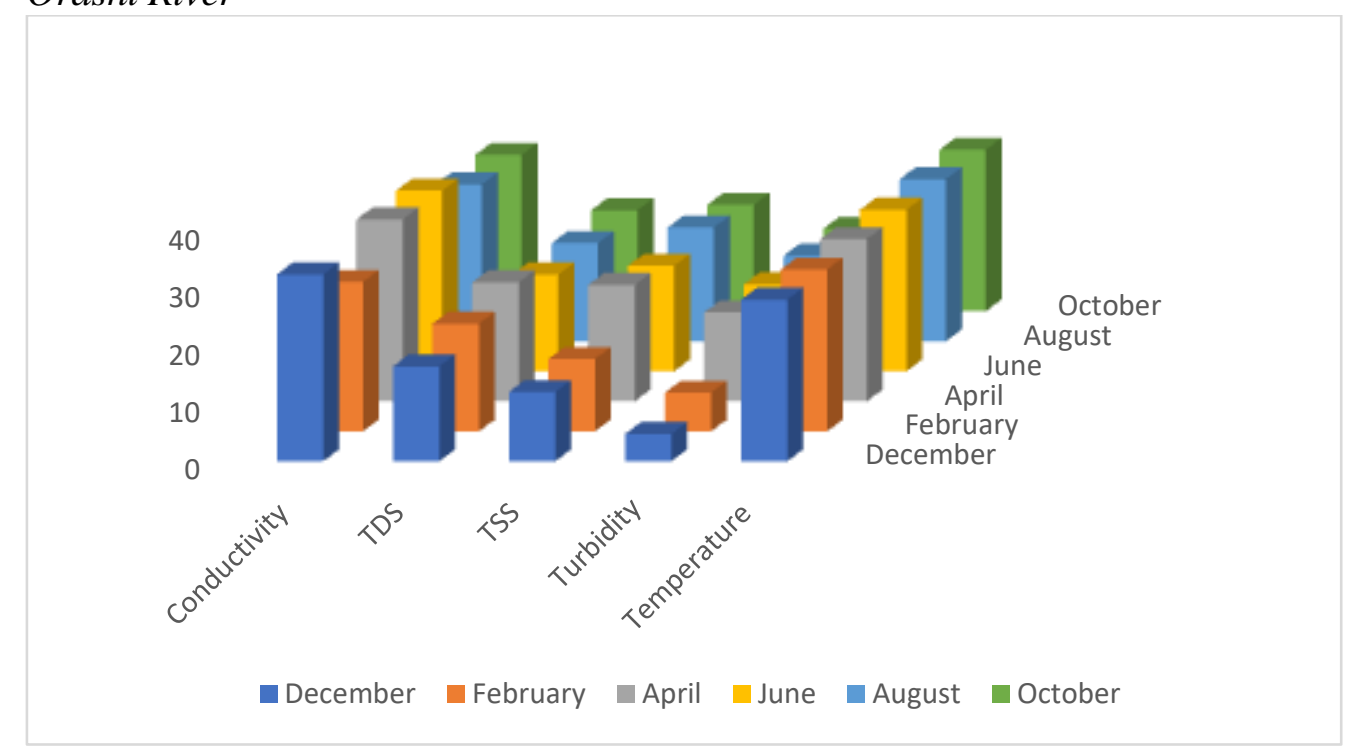

The values of conductivity from the different sample stations ranged from $27.87 \pm 4.45-30.97 \pm 6.66 \mu \mathrm{S} / \mathrm{cm}$. The monthly variations ranged from $25.98 \pm$ $4.36 \mu \mathrm{S} / \mathrm{cm}$ in February to $32.53 \pm 5.28 \mu \mathrm{S} / \mathrm{cm}$ in December. The conductivities of the different water samples from both stations and months were lower than the WHO and NAFDAC value of $1000 \mathrm{mg} / \mathrm{L}$. The observed values of conductivity in the water were higher than those of Ukenye and Taiwo (2019), but lower than the values observed by other authors (Chandra et al. 2011, Nguyen and Cai 2019, Mbalassa et al. 2014). However, the observed values are in agreement with the observation of Edori (2020), in another water body that is a tributary of the Orashi River.

The conductance of any medium is referred to as electrical conductivity. It is used to evaluate the ability of water to transport electric current. It gives an overview of the quantity of salts in solution (Edori et al. 2020). The measured values of conductivity in the different stations and months were below the FAO limit fixed for agricultural irrigation (Ayers and Westcot 1994). The low values of conductivity can further be explained that the water from adjoining creeks, streams and runoffs which empties into the Orashi River contains very low amount soluble inorganic matter present in ionic forms. When the electrical conductivity is high, the implication is that little quantity of water will be made available to plants if used for irrigation. This is because the transpiration process of plants only requires water that is as pure as possible. The rate of water usage by plant in the soil solution decreases as the value of conductivity increases. Thus, the productivity of plants is reduced when planted in soil irrigated with water that has high conductance value (Mezgebe et al. 2015).

The values observed for total dissolved solids from the different stations ranged from $5.29 \pm 2.39-21.00 \pm 4.61 \mathrm{mg} / \mathrm{L}$, while the variations within the months were $16.52 \pm 3.68$ in December to $20.70 \pm 4.11 \mathrm{mg} / \mathrm{L}$ in April. Values of TDS observed in the river were lower than the $1500 \mathrm{mg} / \mathrm{L}$ value recommended by 
the World Health Organization (WHO). The values of this work were higher than those of Edori et al. (2020), in Elelenwo River, but within the range of values observed in Ishasha River and Lake Edward (Mbalassa et al. 2014), yet lower than those of Adewuyi et al. (2017) in Yewa River ogun and Badagry Creek Lagos, Southwest Nigeria and those of Chandra et al. (2011), in different water bodies in India.

The expression of the total amount of matter in solution of water is referred to as Total dissolved solids (TDS). The constituents that are summed up in this parameter are the inorganic salts and part of some soluble organic substances. Notable among the inorganic salts are calcium chloride, magnesium chloride, calcium nitrates and magnesium nitrates (Edori et al. 2019). The presence of elevated concentrations of these salts in the water will result in changes in the characteristics of several systems of water plants and animals. TDS positively correlates with conductivity in water media because of the dependence on each other. High levels of TDS imply the presence of high levels of ionic conducting species in water, which facilitators of conductivity (Thirumalini and Joseph 2009, Iyama et al. 2019). According to Nguyen and Cai (2019) increased content of TDS in water is toxicologically viewed as water contamination

Total dissolved solids present at values lower than $500 \mathrm{mg} / \mathrm{L}$ in water is safe for drinking and aquatic animal life, for example fisheries. Increase in concentrations of TDS reduces its sweetness and portability and when it has grown to levels above $1000 \mathrm{mg} / \mathrm{L}$ will introduce undesired taste to the water. Water with elevated levels of TDS is not good for irrigation, since it will negatively affect the yielding capacity of the soil due to excess salts (Which are conduction species that affects water uptake by plants root. Further to this even when the water has evaporated, the salts are left behind, which thereby increase the salinity of the soil (Chandra et al. 2011). TDS sources include rock weathering due to water current as it moves along its course and from runoffs laden with soluble metallic salts.

TSS concentrations within the stations varied from $15.40 \pm 2.38-18.29 \pm 3.39$ $\mathrm{mg} / \mathrm{L}$. Variations within the months ranged from $12.06 \pm 2.08$ in December $20.25 \pm 3.61 \mathrm{mg} / \mathrm{L}$ in April. All the values of TSS observed in this research were below the $500 \mathrm{mg} / \mathrm{L}$ recommended for drinking water by NAFDAC and WHO. The results of TSS in the present work is lower than the values observed in Agam River in Ethiopia (Mezgebe et al. 2015) and the values observed in Tano River, in Ghana (Nyantakyi et al. 2020).

High value of TSS in water decreases water transparency (Edori et al. 2019). Increased TSS in water can either be through anthropogenic or natural factors. Anthropogenic factors include dredging activities, which lead to resuspension of particles from sediment back to surface water and soil loosening activities such as farming, construction of road, erection of houses and other structures, quarrying, grubbing and direct discharge of wastes (Edori and Nna 2018). Natural factors include algal population, flow pattern of the river which may re-suspend particles from sediment to water, flooding and erosion. The extent of water contamination can be predicted through the amount of TSS present in the water and at very high concentrations will alter the organoleptic properties (taste, odour and colour) of the water and render it non-portable (Edori and Kpee 2016, Edori et al. 2020). 
The values of turbidity in stations varied from $10.32 \pm 4.37-13.62 \pm 1.36$ NTU. The variations of turbidity in the months ranged from $4.75 \pm 1.02$ in December to $15.16 \pm 2.95$ NTU in June. The observed values of turbidity in both stations and months were above the Nigerian NAFDAC and WHO standard of 5.0 NTU for drinking water. The observed values of turbidity in the Orashi River were in consonance with the observations of other authors in similar Niger Delta environment (Nduka et al. 2008, Edori 2020), whose values were equally higher than the 5.0 NTU maximum limit for drinking water. However, the present work values were at variance with those of Nnamani et al. (2015), in Isu and Calabar Rivers, where turbidity values were lower than 5.0 NTU.

Turbidity is used to describe the transparency of water. It is given by the extent of matter that is suspended in the water matrix. When the amount of suspended particles in water is high, the visibility of the water is reduced. At high turbidity, the vision of water inhabiting animals will be reduced and so affects their feeding characteristics and also causes some changes in the environment that are associated with turbidity, namely decreased amount of dissolved oxygen (Starkey and Karr 1984), light penetration, and photosynthesis, which affects primary productivity stages in water such as the growth of zooplanktons and other higher aquatic plants and thus the food chain of the environment.

According to Colman et al. (1992), the ability of fish to breathe and plants to perform photosynthetic activities is affected by turbidity. Turbid water helps to prevent juvenile fishes from attack by predators. This is because the water visibility is affected and so predators find it more difficult to see them for attack. Also, turbid water is more likely to offer more foods for fishes and then provide a path for migration of fishes to or from the river (Blaber 2000). Some of the negative consequences of highly turbid water are reduced number of eggs that are likely to survive, reduced hatchability of eggs, reduction in feeding capacity of filter feeders, reduction in growth rate and population of fish (Whitfield 1998).

The values of temperature in the stations ranged from $28.04 \pm 0.20-28.32 \pm$ $0.21{ }^{\circ} \mathrm{C}$ and in the months, the variation ranged from $28.09 \pm 0.88$ in June to 28.20 $\pm 1.63^{\circ} \mathrm{C}$ in April. The observed values of temperature in all the stations and months did not vary significantly $(\mathrm{P}>0.05)$. They all fall within the WHO and NAFDAC requirement for drinking water. The observed temperature range in the Orashi River is in agreement with observations of other authors on rivers (Edori et al. 2019, Edori et al. 2020) and creek (Edori 2020), in Niger Delta Nigeria.

The rate of metabolism of aquatic plants and animals is greatly affected by the prevailing water temperature. The extent to which the water is hot or cold is consequent on the growth and developmental form of aquatic biomes. Every living plant or animal in water has a range of organism has temperature range that can support optimum growth and survival of their various breeds. Other effects of temperature outside living organisms are alteration in the concentrations of dissolved oxygen in water, nutrients availability and viscous nature of the water. Others are changes in the body reactions of organism and fate of aquatic pollutants (Nguyen and Cai 2019). Generally, the temperature of a flowing water fluctuates slightly depending on variations of temperature during the day, but that of stagnant water is more stable and hotter, since the water do not mix properly (Ortiz-Zayas 
et al. 2005, Dudgeon 2011) and also encourages more biochemical reactions and microbial activities and so stinks after a long period of non-regeneration through precipitation

\section{Gross Organic Pollutants}

The concentrations of the gross organic pollutants are shown in Table 4 and Figure 3. These parameters include dissolved oxygen (DO), biochemical oxygen demand (BOD) and chemical oxygen demand (COD).

Table 4. Gross Organic Pollutants of Water Samples from Orashi River at the Different Stations

\begin{tabular}{|l|c|c|c|c|c|}
\hline \multirow{2}{*}{$\begin{array}{l}\text { Gross Organic } \\
\text { Pollutants }\end{array}$} & \multicolumn{4}{|c|}{ Stations } & \\
\cline { 2 - 6 } & 1 & 2 & 3 & 4 & \\
\hline DO $(\mathrm{mg} / \mathrm{L})$ & $5.95 \pm 1.10$ & $5.71 \pm 1.61$ & $5.80 \pm 0.90$ & $6.18 \pm 1.13$ & $5.91 \pm 0.18$ \\
\hline BOD $(\mathrm{mg} / \mathrm{L})$ & $7.73 \pm 2.23$ & $7.49 \pm 1.25$ & $6.26 \pm 1.24$ & $7.70 \pm 2.23$ & $7.30 \pm 0.60$ \\
\hline COD $(\mathrm{mg} / \mathrm{l})$ & $8.28 \pm 2.21$ & $10.21 \pm 1.21$ & $9.60 \pm 1.18$ & $9.55 \pm 2.17$ & $9.41 \pm 0.70$ \\
\hline
\end{tabular}

Figure 3. Mean Monthly Variation of Gross Organic Pollutants Parameters of Water Samples from Orashi River

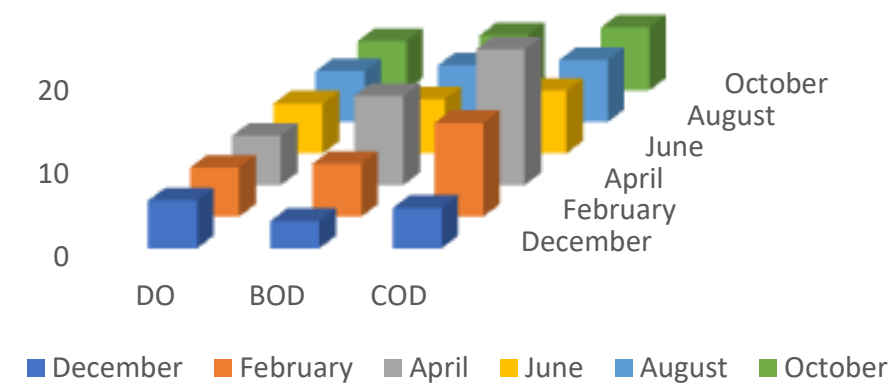

The DO results obtained from the stations ranged from $5.71 \pm 1.61-6.18 \pm$ $1.13 \mathrm{mg} / \mathrm{L}$, while those months varied from $5.71 \pm 1.04$ in December to $6.06 \pm$ $1.68 \mathrm{mg} / \mathrm{L}$ in August. The observed values of DO in the present work were lower than the standard requirement of $10 \mathrm{mg} / \mathrm{L}$ by the relevant agencies (WHO and NAFDAC). The values of DO in the present work fall within the range observed in River Tano in Ghana (Nyantakyi et al. 2020) and those of Ukenye and Taiwo (2019), in some coastal waters of some Nigerian Rivers, but were higher than the values observed in Tsaeda Agam River in Mekelle City, Tigray, Ethiopia (Mezgebe et al. 2015).

The amount of DO in water is dependent on the prevalent temperature of the water. The temperature of the water is inversely related to the temperature and so high temperature portends low oxygen solubility. However, the temperature of any water body varies at intervals during the day and also, the amount soluble oxygen in the water is likely to vary. The changes in the amount of oxygen in water are not 
only affected by temperature but also the flow nature of the water, the amount and speed of wind that passes through the water surface, the pressure of the atmosphere (Nduka et al. 2008) and the nature of plants growing in the water which respire. According to Nguyen and Cai (2019) concentration of DO up to 5 $\mathrm{mg} / \mathrm{L}$ can support aquatic life, when it is lower than $2 \mathrm{mg} / \mathrm{L}$ is lethal to fishes and adversely affect function and survival of biological communities, and below 2 $\mathrm{mg} / \mathrm{L}$ can lead to death of fish that are not adapted to such conditions.

When the DO value is low (within $3 \mathrm{mg} / \mathrm{L}$ and below), it causes reduction in fish population through prolonged hatching time of fish eggs, reduction in the size of and strength of embryos. DO is responsible for redox reactions that take place in water and as a result of the redox reactions, changes the chemical and physical states of the species involved and as such can change the portability of the water (Nduka et al. 2008). The nature of life in natural aquatic surroundings is dependent on the quantity of DO present. Most microbes make use of available DO for replication (Edori and Nna 2018)

The values of BOD in the water samples from stations varied from $6.26 \pm$ $1.24-7.73 \pm 2.23 \mathrm{mg} / \mathrm{L}$. in the months, the variations ranged from $3.28 \pm 0.33$ in December to $10.68 \pm 2.64 \mathrm{mg} / \mathrm{L}$ in April. The BOD concentrations in the Orashi River were higher than the limit value given by WHO. The values of BOD in the present work fall within the range of values observed in a brackish water environment (Iyama and Edori 2014), but higher than those of Mezgebe et al. (2015), in Tsaeda Agam River in Mekelle City, Tigray, Ethiopia. However, these values were very low when compared with the values observed in a Ghanaian water body called Tano River, where BOD values ranged from 9-78 mg/L (Nyantakyi et al. 2020)

Biochemical oxygen demand (BOD) is a measure of the quantity of oxygen that is involved when bacteria is breaking down organic matter to simpler matter in aquatic medium. It gives underlying information on the available concentration of biological materials existing in water. The level of organic matter present in water is commensurate with the amount of oxygen demanded (Edori et al. 2019), which implies that BOD is dependent on the amount of biodegradable substances present in water, which when high cause a reduction in available DO (Ubwa et al. 2013). When substances decay, they make use the available oxygen in the water and so reduce its quantity and then the quality of water. Reduced oxygen content of water at certain level can cause the water to stink and thereby cause mortality of aquatic animal, but in stagnant water, the organisms may likely die.

The values of COD within the stations varied from $8.28 \pm 2.21-10.21 \pm 1.21$ $\mathrm{mg} / \mathrm{L}$. In the months, the observed variation ranged from $4.85 \pm 1.15$ in December to $16.24 \pm 3.22 \mathrm{mg} / \mathrm{L}$ in April. The observed values of COD in the river were either lower or higher than the $10 \mathrm{mg} / \mathrm{L}$ limit stipulated by NAFDAC and WHO for Drinking water. The values of COD in the present work were lower than those of Nyantakyi et al. (2020), in Tano River, Ghana and those of Kamal et al. (2007), in Mouri River, Khulna, Bangladesh.

The level of COD in water is a function of the amount of organic matter that is present in the water which undergoes chemical oxidation. The redox reaction of organic matter in water is dependent of the available DO in the water. The 
oxidation-reduction possibility that can take place in any water body is factored on the volume of oxygen that can oxidize efficiently the organic substance existent in the water. COD is a measure of the quantity of DO that is consumed to complete oxidation (Sharma and Walia 2017), which is also responsible for reduction in the oxygen holding capacity of the water and detrimental to aquatic organisms (Hagai 2018). COD like BOD is a useful tool in health risk assessment before water is distributed to households for use (Edori et al. 2019).

The inputs of substance into water that are not subject to biodegradation give rise to elevated COD (Elayaraj and Selvaraju 2015). In most cases, higher values of COD are observed in rainy seasons as compared to dry seasons due to increased concentration of non-biodegradable matter discharged into the river through runoffs and used water into the river through runoffs and effluent discharges (Nyantakyi et al. 2020). Also during wet season, the rising tide due to flooding attracts more organic matter into the river which increases the organic water content and thus the COD of the water.

\section{Nutrient Parameters}

The values of the nutrient parameters in the Orashi River are shown in Table 5 and Figure 4. The nutrient parameters include nitrates $\left(\mathrm{NO}_{3}{ }^{-}\right)$, sulphates $\left(\mathrm{SO}_{3}{ }^{2-}\right)$ and phosphates $\left(\mathrm{PO}_{4}{ }^{3-}\right)$.

Table 5. Nutrient Parameters of Water Samples from Orashi River at the Different Stations

\begin{tabular}{|c|c|c|c|c|c|}
\hline \multirow{2}{*}{$\begin{array}{l}\text { Nutrient } \\
\text { Parameters }\end{array}$} & \multicolumn{4}{|c|}{ Stations } & \\
\hline & 1 & 2 & 3 & 4 & \\
\hline $\mathrm{NO}_{3}{ }^{-}(\mathrm{mg} / \mathrm{L})$ & $3.19 \pm 0.88$ & $3.60 \pm 0.97$ & $3.75 \pm 1.21$ & $3.12 \pm 0.11$ & $3.42 \pm 0.27$ \\
\hline $\mathrm{SO}_{4}{ }^{2-}(\mathrm{mg} / \mathrm{L})$ & $1.98 \pm 0.09$ & $1.18 \pm 0.21$ & $1.03 \pm 0.10$ & $0.41 \pm 0.09$ & $1.15 \pm 0.56$ \\
\hline $\mathrm{PO}_{4}{ }^{3-}(\mathrm{mg} / \mathrm{L})$ & $6.89 \pm 1.41$ & $14.77 \pm 2.44$ & $18.36 \pm 3.42$ & $22.58 \pm 4.40$ & $15.65 \pm 5.76$ \\
\hline
\end{tabular}

Figure 4. Mean Monthly Variation of Physicochemical Parameters of Water Samples from Orashi River

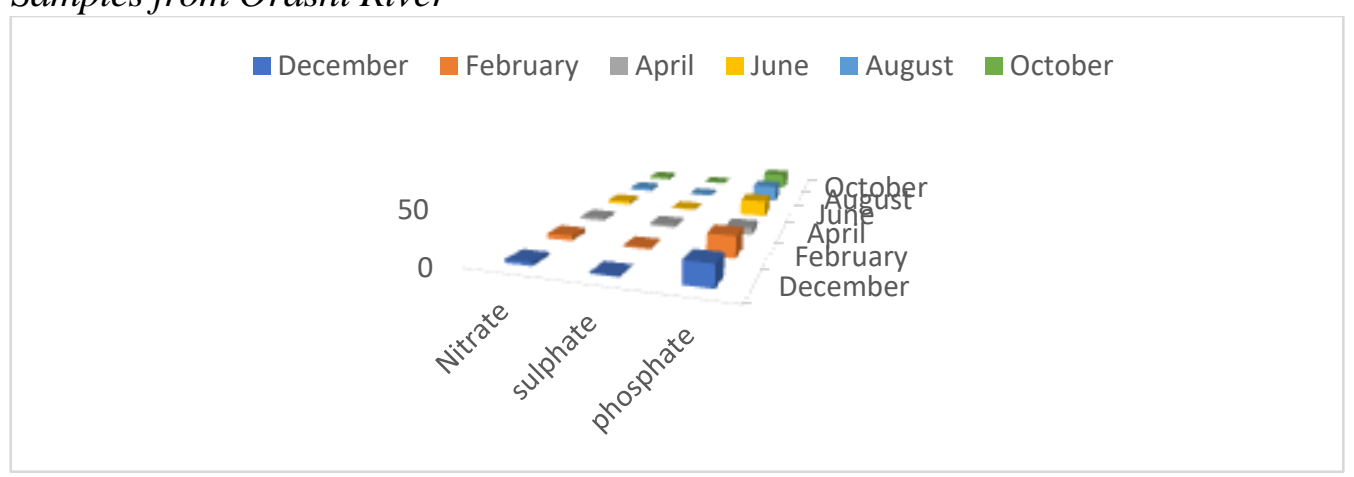

Stations variations in nitrates concentrations ranged from $3.12 \pm 0.11-3.75 \pm$ $1.21 \mathrm{mg} / \mathrm{L}$. In the months the values varied from $2.67 \pm 0.05$ in April to $4.72 \pm$ $1.01 \mathrm{mg} / \mathrm{L}$ in February. The values of nitrates observed in all the stations and months in the river were lower than the required value for drinking water by $\mathrm{WHO}$ 
$(10 \mathrm{mg} / \mathrm{L})$ and NAFDAC $(20 \mathrm{mg} / \mathrm{L})$. The value of nitrates observed in water from the Orashi River is slightly higher than the values observed in brackish water environment in the Niger Delta Nigeria (Iyama and Edori 2014), but are within the range of values observed in surface water in Sagbama Creek, Bayelsa State, Nigeria (Iyama et al. 2019).

Nitrates originate from bacterial oxidation of organic nitrogen either in water or soil in the presence of abundant supply of oxygen. Nitrates are important plant nutrients and are useful for irrigation when present in water. However, increased values of nitrates in water lead to algal bloom, enhanced growth of aquatic plants, promotion of eutrophication and water pollution (Sinha and Biswas 2011). Ammonium nitrogen in wastewater is one source of nitrates in aquatic surroundings (Ali et al. 1996). Consumption of water with levels of nitrates greater than $45 \mathrm{mg} / \mathrm{L}$ can lead to methaemoglobinemia in children and expectant mothers (Kross et al. 1993).

Farming activities and burning of fossils can increase nitrate concentration (Iyama et al. 2019). When there is a sudden increase in nitrate concentrations, the biological dynamics of the waterbody is changed, turbidity is increased, more oxygen is consumed, increased presence of algae, increased growth of higher aquatic plants and increased harm to fishes (Edori et al. 2020).

The values sulphates observed in the sampled stations ranged from $0.41 \pm$ $0.09-1.98 \pm 0.09 \mathrm{mg} / \mathrm{L}$. In the months the values varied from $0.83 \pm 0.03$ in December to $2.52 \pm 0.00$ in April. The observed values of sulphate were lower than the WHO and NAFDAC value of $500 \mathrm{mg} / \mathrm{L}$. The amount of sulphates present in the Orashi River is lower than the WHO limit for drinking water. The value of sulphate in the present research were lower than the value of Ukenye and Taiwo (2019) in eleven (11) coastal waters in the Niger Delta, Nigeria and also those of Kamal et al. (2007), in Mouri River Khulna, Bangladesh, but within the value range observed in Ede Onyima Creek in Okarki Engenni, Rivers State, Nigeria (Edori 2020).

In water, sulphate is considered to be the least poisonous anions. Despite its low toxicity, it has been linked with some body disorders which include purging, lack of moisture and intestinal irascibility when present at concentration above the stipulated value of $500 \mathrm{mg} / \mathrm{L}$ (Bertram and Balance 1996). Sources of sulphate in water are discharges from industrial effluents, Sulphur mines, sulphuric acid production processes, heating of metals containing sulphur compounds (tanneries), paper mills and from precipitation by rain from atmosphere laden with Sulphur dioxide (Andrews et al. 2004). High content of sulphate in water increases acidity of the water and hence increased concentration of sulphate bound bacteria.

The values of phosphate observed in the stations in varied from $6.89 \pm 1.41$ $22.58 \pm 4.40 \mathrm{mg} / \mathrm{L}$. The variation $6.74 \pm 1.06$ in April to $20.13 \pm 3.88 \mathrm{mg} / \mathrm{L}$ in February. The values of phosphate observed in the present work at the different rivers showed that the values exceeded the WHO standard of $0.5 \mathrm{mg} / \mathrm{L}$ for domestic water use, but were either higher or lower than the NAFDAC requirement of $10 \mathrm{mg} / \mathrm{L}$. The observed values of phosphate in Orashi River is higher than the values of Nduka et al. (2008), Nnamani et al. (2015) and Mezgebe et al. (2015), in different rivers. 
Phosphates are introduced into the aquatic environment in the form of phosphorus. Although the presence of other chemical parameters may enhance eutrophication, yet the known major cause of eutrophication are the phosphates (Wagner 1974). Phosphorous as a vital nutrient required for growth and proper functions of cells is absorbed into cells and tissues in the form of phosphates. Phosphate compounds in cell set-up energy produced from food intake and transports them to actions that require it for some biological functions such as movement, replication and development. The absence of phosphorus (which are generated by phosphate reactions), it become difficult for high energy compounds such as ATPase to be formed (Edori et al. 2015), which will be deleterious for the continuation of cell life (Adeyemi et al. 2012, Edori et al. 2013).

\section{Conclusions}

The findings of this research revealed that the water from the Orashi River was slightly contaminated. This is evidenced from the observed values of turbidity, DO, BOD and partly those of COD and phosphates. Other parameters which include $\mathrm{pH}$, salinity, $\mathrm{Cl}^{-}$, conductivity, TDS, TSS, turbidity, temperature, $\mathrm{NO}_{3}{ }^{-}$and $\mathrm{SO}_{4}{ }^{2}$ - were within the $\mathrm{WHO}$ acceptable limit required for drinking purposes. The contamination sources are likely of organic origin that may have originated from enormous amount or organic wastes discharged directly into the river by the inhabitants of the area investigated and flood water carrying plant materials during the rainy periods. Therefore, the water should be given some form of treatment before being consumed.

\section{References}

Adewuyi GK, Badejo OT, Idowu FF, Ogunjobi GA, Gbopa AO (2017) Analysis of physico-chemical parameters: an empirical study of Yewa River Ogun and part of Badagry Creek lagos, Southwest Nigeria. International Journal of Hydrology 1(7): 202-211.

Adeyemi JA, Deaton LF, Peesacreta TC, Klerks PL (2012) Effects of copper on osmoregulation in sheepshead minnow, Cyprinodon variegates acclimated to different salinities. Aquatic Toxicology 109(Mar): 111-117.

Ali K, Javid A, Javid M (1996) Pollution and industrial waste, Lahore. In $6^{\text {th }}$ National Congress Soil Sciences, Lahore, Pakistan.

American Public Health Association - APHA (1995) Standard methods for the examination of water and waste water. $19^{\text {th }}$ Edition. Washington, DC: APHA.

Andrews JE, Brimblecombe P, Jickells TD, Liss PS, Reid B (2004) An introduction to environmental chemistry. $2^{\text {nd }}$ Edition. UK: Blackwell Science Ltd.

Ayers RS, Westcot DW (1994) Water quality for agriculture, FAO Irrigation and Drainage Paper Water. Rome.

Bay S, Jones BH, Schiff K, Washburn L (2003) Water quality impacts of stormwater discharges to Santa Monica Bay. Marine Environmental Research 56(1-2): 205-23. 
Bere T, Tundisi JG (2011) Influence of ionic strength and conductivity on benthic diatom communities in a tropical river (Monjolinho), São Carlos-SP, Brazil. Hydrobiologia 661(Nov): 261-276.

Bertram J, Balance R (1996) A Practical guide to the design and implementation of freshwater, quality studies and monitoring programmes. United Nations Environmental Programme (UNEP) and World Health Organization (WHO), E \& FN Spoon Publishers, 172-177, 192-196.

Blaber SJM (2000) Tropical estuarine fishes. Ecology, Exploitation and Conservation. Fish and Aquatic Resources Series 7. Blackwell Science.

Chandra S, Singh A, Kumar Tomar PK, Kumar A (2011) Evaluation of physicochemical characteristics of various river water in India. E-Journal of Chemistry 8(4): 15461555.

Colman J, Lardinois P, Rabelahatra A, Rafaliarison J, van den Berg F, Randriamiarana H, Johannes J (1992) Manuel pour le Développement de la Pisciculture à Madagascar, FI: DP/MAG/88/005. (Manual for the Development of Fish Farming in Madagascar, FI: DP / MAG / 88/005). Document Technique N². PNUD/FAO-MAG/88/005. Antsirabe.

Dudgeon D (2011) Tropical stream ecology. London: Academic Press.

Edori OS (2020) Physical and Chemical Characteristics of Water from Ede Onyima Creek, Okarki-Engenni, Rivers State, Nigeria. Chemistry Research Journal 5(3): 144-154.

Edori OS, Dibofori-Orji AN, Edori ES (2013) Biochemical changes in plasma and liver of Clarias gariepins exposed to paraquat. IOSR Journal of Pharmacy and Biological Sciences 8(2): 35-39.

Edori OS, Dibofori-Orji AN, Edori ES (2015) Comparative effects of kerosene and diesel on ion regulatory characteristics in Tympanotonus fuscatus after subchronic exposure. International Journal of Biochemistry Research and Review 8(3): 1-6.

Edori OS, Kpee F (2016) Physicochemical and heavy metal assessment of water samples from boreholes near some abattoirs in Port Harcourt, Rivers State, Nigeria. American Chemical Science Journal 14(3): 1-8.

Edori OS, Nna PJ (2018) Determination of physicochemical parameters of effluents at discharge points into the New Calabar river along Rumuolumeni axis, Niger Delta, Nigeria. Journal of Environmental and Analytical Toxicology 8(3): 1000585.

Edori OS, Kpee F (2018) Assessment of heavy metals content in water at effluents discharge points into the New Calabar river, Port Harcourt, Southern Nigeria. Global Journal of Science Frontier Research (B) 18(2): 52-58.

Edori OS, Kieri BSI, Festus C (2019) Physicochemical characteristics of surface water and sediment of Silver river, Southern Ijaw, Bayelsa State, Niger Delta, Nigeria. American Journal of Environmental Science and Engineering 3(2): 39-46.

Edori OS, Iyama WA, Amadi MC (2020) Variation of some physicochemical parameters of surface water of Elelenwo river, Rivers State, Niger Delta. Nigeria. International Journal of Research and Scientific Innovation 7(5): 230-235.

Elayaraj B, Selvaraju M (2015) Seasonal variations in physico-chemical parameters of Sri Kamatchiamman Temple Pond Chidambaram Taluk, Tamilnadu. Journal of Environmental Treatment Techniques 3(2): 126-133.

Fakayode SO (2005) Impact assessment of industrial effluent on water quality of the receiving Alaro River in Ibadan, Nigeria. Computational Water, Energy, and Environmental Engineering 10(Mar): 1-13.

Hagai M (2018) Relationship between land cover changes with water quantity in lake Victoria-A case study of Mara river basin in Tanzania. Journal of Environmental Science and Engineering B 7(Jan): 28-34. 
Iyama WA, Edori OS (2014) Seasonal variation in water quality during dredging of brackish water habitat in the Niger Delta, Nigeria. Trends in Applied Sciences Research 9(3): 153-159.

Iyama WA, Edori OS, Ede PN (2019) Physicochemical assessment of surface water quality around the Sagbama creek water body, Bayelsa State, Nigeria. Global Journal of Science Frontier Research B: Chemistry 18(2): 1-10.

Iyama WA, Edori OS, Nwagbara VU (2020) Assessment of the pollution load of the Woji creek water body, Port Harcourt, Rivers State, South-South, Nigeria. International Journal of Advanced Research in Chemical Science 7(1): 1-8.

Kamal D, Khan AN, Rahman MA, Ahamed F (2007) Study on the physicochemical properties of water of Mouri river, Khulna, Bangladesh. Pakistan Journal of Biological Sciences 10(5): 710-717.

Kross BC, Hallberg GR, Bruner DR, Cherryholmes K, Johnson JK (1993) The nitrate contamination of private well water in Iowa. American Journal of Public Health 83(2): 270-272.

Lawson EO (2011) Physico-chemical parameters and heavy metal contents of water from the Mangrove Swamps of Lagos Lagoon, Lagos, Nigeria. Biological Resources 5(1): $8-21$.

Mbalassa M, Bagalwa MJJ, Nshombo M, Kateyo ME (2014) Assessment of physicochemical parameters in relation with fish ecology in Ishasha river and lake Edward, Albertine Rift Valley, East Africa. International Journal of Current Microbiology and Applied Sciences 3(6): 230-244.

Mezgebe K, Gebrekidan A, Hadera A, Weldegebriel Y (2015) Assessment of physicochemical parameters of Tsaeda Agam river in Mekelle city, Tigray, Ethiopia. Bulletin of Chemical Society of Ethiopia 29(3): 377-385

Nduka JK, Orisakwe OE, Ezenweke LO (2008) Some physicochemical parameters of potable water supply in Warri, Niger Delta area of Nigeria. Scientific Research and Essay 3(11): 547-551.

Nguyen CTT, Cai Y (2019) Physicochemical characteristics of streams in Bukit Timah Nature Reserve, Singapore. Gardens'B Bulletin Singapore 71(May): 491-556.

Nnamani EV, Akpagu FC, Eze-Chukwuebuka GI (2015) The analysis of selected physicochemical parameters of water (A case study of ISU and Calabar rivers in Ebonyi State, Nigeria). IOSR Journal of Applied Chemistry (IOSR-JAC) 8(1): 21-25.

Nyantakyi JA, Fei-Baffoe B, Akoto O (2019) Seasonal variations in physicochemical and nutrient water quality of river Tano in Ghana. International Journal of Environmental Chemistry 4(1): 1-12.

Ortiz-Zayas JR, Lewis Jr WM, Saunders III JF, McCutchan Jr JH, Scatena FN (2005) Metabolism of a tropical rainforest stream. Journal of the North American Benthological Society 24(4): 769-783.

Saksena D, Kaushik S (1994) Trophic status and habitat ecology of entomofauna of three water bodies at Gwalior, Madhya Pradesh in perspective in entomological research. Edited by OP Agarwal. Scientific Publishers: Jodhpur, India.

Sharma N, Walia YK (2017) Water quality investigation by physicochemical parameters of Satluj river (Himachal Pradesh, India). Current World Environment 12(1): 174180.S

Sinha SN, Biswas M (2011) Analysis of physico-chemical characteristics to study the water quality of a lake in Kalyani, West Bengal. AJEBS 2(1): 18-22.

Starkey J, Karr P (1984) Effect of low dissolved oxygen concentration on effluent turbidity. Journal (Water Pollution Control Federation) 56(7): 837-843.

Thirumalini S, Joseph K (2009) Correlation between electrical conductivity and total dissolved solids in natural waters. Malaysian Journal of Science 28(1): 55-61. 
Ubwa ST, Abah J, Ada CA, Alechenu E (2013) Levels of some heavy metals contamination of street dust in the industrial and high traffic density areas of Jos Metropolis. Journal of Biodiversity and Environmental Sciences 3(7): 13-21.

Ukenye EA, Taiwo IA (2019) Studies on the physico chemical status and biological characteristics of some rivers in Nigerian coastal states. International Journal of Fisheries and Aquatic Studies 7(3): 192-196.

Wagner RH (1974) Environment and man. New York: W.W. Norton and Company.

Whitfield AK (1998) Biology and ecology of fishes in Southern African estuaries. Ichthyological Monographs of the J. L. B. Smith Institute of Ichthyology, No. 2.

Wokoma OAF, Edori OS (2017) Heavy metals content of an oily wastewater effluent from an oil firm at the point of discharge. International Journal of Chemistry, Pharmacy and Technology 2(4): 154-161.

World Health Organization - WHO (2003) Chloride in drinking-water background document for development. WHO guidelines for drinking-water quality. $2^{\text {nd }}$ Edition. Geneva: WHO. 
